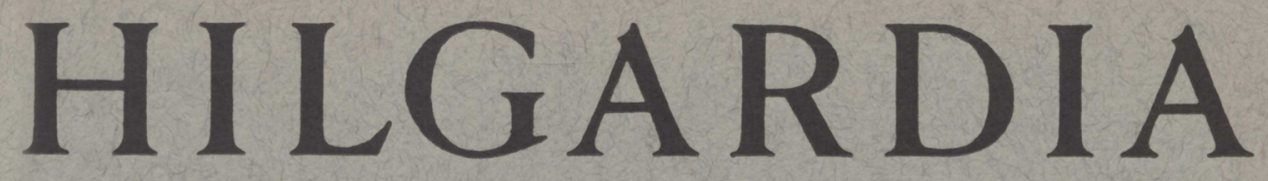

A Journal of Agricultural Science Publisbed by the California Agricultural Experiment Station

\title{
GYPSUM, SULFUR, AND SULFURIC ACID FOR RECLAIMING AN ALKALI SOIL OF THE FRESNO SERIES
}

ROY OVERSTREET, J. C. MARTIN, and H. M. KING 
This paper is a report of recent experiments in the use of gypsum, sulfuric acid, and sulfur in the reclamation of a severely affected alkali soil of the Fresno series. Effects of the soil correctives on the yield of irrigated pasture are compared statistically.

Treatment consisted of applications of the chemicals on the basis of the same sulfur content ( 1.86 tons) per acre. Resulting yields of the sulfuric-acid plots (5.70 tons $\mathrm{H}_{2} \mathrm{SO}_{4}$ per acre) were markedly higher than those of the gypsum ( 10 tons per acre) and sulfur plots over the two-year period following treatment.

Yields of the sulfur plots were never significantly higher than those of the check plots, probably because the sulfur had not had time to oxidize. Yields of the gypsum plots were significantly higher than the sulfur-plot yields for the initial cuttings, but 20 months after application there was no significant difference.

Reduced $\mathrm{H}_{2} \mathrm{SO}_{4}$ applications on the same soil ( 2.85 and 1.42 tons per acre) also gave pronounced beneficial effects. Greenhouse experiments indicate that improvement may be expected from applications as small as 0.4 tons $\mathrm{H}_{2} \mathrm{SO}_{4}$ per acre. 


\title{
$\begin{array}{lllllllll}H & I & L & G & A & R & D & I & A\end{array}$
}

A Journal of Agricultural Science Published by

the California Agricultural Experiment Station

\section{GYPSUM, SULFUR, AND SULFURIC ACID FOR RECLAIMING AN ALKALI SOIL OF THE FRESNO SERIES ${ }^{1,2}$}

\author{
ROY OVERSTREeT, ${ }^{3}$ J. C. MARTIN, and H. M. KING ${ }^{5}$
}

\section{INTRODUCTION}

THE BASIC PHYSICAL and chemical principles involved in the reclamation of alkali lands are now reasonably well established. This present state of enlightenment regarding alkali is largely the result of the researches of such investigators as K. K. Gedroiz, D. J. Hissink, E. W. Hilgard, W. P. Kelley, Elek de'Sigmond, and many others.

In general, it has been widely confirmed that the reclamation of any alkali soil requires as first essentials (1) good drainage, (2) an abundant supply of suitable irrigation water, and (3) good farming methods such as leveling, strict adherence to a plan of operation, etc. Actually, these factors alone usually suffice for the reclamation of soils of the purely saline type.

Soils that contain harmful amounts of adsorbed or exchangeable sodium ordinarily cannot be reclaimed readily by leaching under conditions of good drainage. Soils characterized by a high amount of exchangeable $\mathrm{Na}$ will be referred to in the present writing as "sodic" alkali soils. In adopting this nomenclature, the authors have preserved the historical meaning of the term "alkali" as a general class name denoting soils with high sodium contents either in the form of free salts or in the adsorbed state. At the same time, the little-used adjective "sodic" (containing sodium) has been chosen to denote undesirably high amounts of adsorbed sodium. Thus we visualize alkali soils of saline, sodic, and saline-sodic types.

Usually, for the reclamation of sodic alkali soils, some soil treatment is required that will result in the replacement of the adsorbed sodium with calcium.

${ }^{1}$ Manuscript submitted April 12, 1951.

2 The writers gratefully acknowledge the coöperation of the staff of the Fresno County Farm Advisor's Office. We are especially indebted to Mr. Ralph M. Arms, Farm Advisor, and to Mr. C. H. Upton, owner of the farm on which much of this work was conducted.

${ }^{3}$ Professor of Soil Chemistry and Soil Chemist in the Experiment Station, Berkeley.

${ }^{4}$ Associate Chemist in the Experiment Station, Division of Plant Nutrition, Berkeley.

${ }^{5}$ Principal Laboratory Technician in Soils, Berkeley. 
The treatment most commonly used is gypsum $\left(\mathrm{CaSO}_{4} \cdot 2 \mathrm{H}_{2} \mathrm{O}\right)$. This compound effects the replacement of adsorbed sodium according to the following reaction:

$$
2 \mathrm{Na}(\mathrm{ad})+\mathrm{CaSO}_{4} \rightarrow \mathrm{Ca}(\mathrm{ad})+\mathrm{Na}_{2} \mathrm{SO}_{4}
$$

where the suffix (ad) signifies the adsorbed state. The sodium sulfate produced is subsequently removed from the soil by leaching with irrigation water.

With sodic soils containing sufficient amounts of undissolved limestone $\left(\mathrm{CaCO}_{3}\right)$, elemental sulfur and sulfuric acid are commonly used as soil correctives in reclamation. Since the elemental sulfur is converted to sulfuric acid through the action of soil microorganisms, these two treatments are theoretically equivalent except for the time required for the biological oxidation of the sulfur. Under the most efficient conditions, the action of sulfur or sulfuric acid in releasing adsorbed sodium can be described by the reaction:

$$
\mathrm{H}_{2} \mathrm{SO}_{4}+2 \mathrm{CaCO}_{3}+4 \mathrm{Na}(\mathrm{ad}) \rightarrow 2 \mathrm{Ca}(\mathrm{ad})+\mathrm{Na}_{2} \mathrm{SO}_{4}+2 \mathrm{NaHCO}_{3} \text {. }
$$

The soluble sodium salts, $\mathrm{Na}_{2} \mathrm{SO}_{4}$ and $\mathrm{NaHCO}_{3}$, are removed from the soil by leaching with irrigation water.

Under the least efficient conditions the action of sulfur or sulfuric acid can be described as follows :

$$
\mathrm{H}_{2} \mathrm{SO}_{4}+\mathrm{CaCO}_{3}+2 \mathrm{Na}(\mathrm{ad}) \rightarrow \mathrm{Ca}(\mathrm{ad})+\mathrm{Na}_{2} \mathrm{SO}_{4}+\mathrm{CO}_{2}+\mathrm{H}_{2} \mathrm{O},
$$

the gaseous carbon dioxide formed being lost to the atmosphere.

Thus it can be seen from the above equations that most efficiently one atom of sulfur is associated with the release of four atoms of adsorbed sodium, whereas least efficiently one atom of sulfur is associated with the release of two atoms of sodium. In field experiments Kelley has found that, in the use of elemental sulfur, one atom of sulfur suffices for the release of approximately three atoms of adsorbed sodium. The corresponding efficiency of field applications of sulfuric acid has not been determined. Nonetheless on theoretical grounds it might be expected that applications of both sulfur and sulfuric acid would be more efficient in removing exchangeable sodium than applications of gypsum, since as can be seen from equation (1), one atom of sulfur in this substance corresponds to the release of only two atoms of sodium.

In addition to the above-mentioned inorganic chemical treatments, the removal of exchangeable sodium from calcareous alkali soils is sometimes accomplished simply by the growing of tolerant plants or by the application of organic materials such as barnyard manures. The efficacy of these materials is due to the production of carbonic acid through respiration of the plant roots or through decomposition of the organic matter by soil microorganisms. The carbonic acid thus produced reacts as follows :

$$
\mathrm{H}_{2} \mathrm{CO}_{3}+\mathrm{CaCO}_{3}+2 \mathrm{Na}(\mathrm{ad}) \rightarrow \mathrm{Ca}(\mathrm{ad})+2 \mathrm{NaHCO}_{3} \text {. }
$$

The soluble $\mathrm{NaHCO}_{3}$ is removed by leaching. Usually this type of reclamation is a slow process and at least in California has not been employed in largescale operations. At the present time, alkali-soil reclamation in the state employs very largely either gypsum, sulfur, or sulfuric acid.

\footnotetext{
${ }^{\circ}$ Private communication.
} 
It will be evident from the foregoing discussion that the three major amendments used in alkali-soil reclamation theoretically are not equally effective on the basis of the same sulfur content. Moreover, the materials differ considerably in price on the basis of the same sulfur content. For example, the current price of gypsum, sulfur, and sulfuric acid wholesale is $\$ 10, \$ 48$, and $\$ 37$ per ton, respectively. Thus on the basis of the same sulfur content (one ton) the wholesale price of the chemicals is gypsum, $\$ 54$; sulfur, $\$ 48$; and sulfuric acid, $\$ 113$.

In view of the great uncertainty as to the relative effects in the field of applications of gypsum, sulfur, and sulfuric acid in the reclamation of sodic alkali soils that contain $\mathrm{CaCO}_{3}$, and the important differences in price of these materials, a careful comparison of the effects of the chemicals seemed highly desirable. Such a comparison has been made in the present research, using a soil from the Fresno region that could be considered representative of a large affected area.

\section{FIELD EXPERIMENTS}

\section{First Experiment}

A field experiment was carried out on an alkali soil of the Fresno series in which applications of gypsum, sulfur, and sulfuric acid were made on the basis of the same sulfur content (1.86 tons of $S$ per acre). The plots were situated on the C. H. Upton farm southwest of the town of Kerman, California ( $41 / 2$ miles south and $3 / 4$ mile west of Kerman). The area selected had been planted to cotton. However, in the approximately $21 / 2$ acres occupied by the plots, scarcely any plants had germinated (figure 1 ).

The experimental area was underlain by a dense hardpan layer of about six inches in thickness. The depth of the dense layer was extremely variable, even over short distances, the range of variation being from 10 inchess to four feet nine inches below the surface.

The land for the experiments was leveled on November 1-6, 1948, and 24 consecutive plots were laid out in strip checks, each 15 feet wide and 300 feet long. In order to facilitate the infiltration of water an attempt was made to break up the hardpan, at least partly, by means of a single chisel which penetrated about 26 inches into the soil. The chisel was drawn twice down each plot at an interval of about four feet.

On November 12 and December 6, 1948, the plots were systematically sampled at one-foot intervals down to the hardpan. Table 1 is a summary of analyses of surface samples (0-12') taken 100 feet from the east end of each plot. Although complete analyses of samples from other points in the plots and at lower depths were made, they are not presented, because they do not show significant trends away from those of the surface samples of the table. The base exchange capacities reported in the table were determined by the usual ammonium acetate method. The values for exchangeable sodium were calculated as the differences between the $\mathrm{NH}_{4} \mathrm{Ac}$-extractable $\mathrm{Na}$ and the watersoluble $\mathrm{Na}$ (1:5 extract). The values for percentage sodium saturation in excess of 100 per cent will be discussed later (p. 124).

In view of the unusually high percentage sodium saturation of this salinesodic soil, it was concluded that the amendments should be applied at rather 


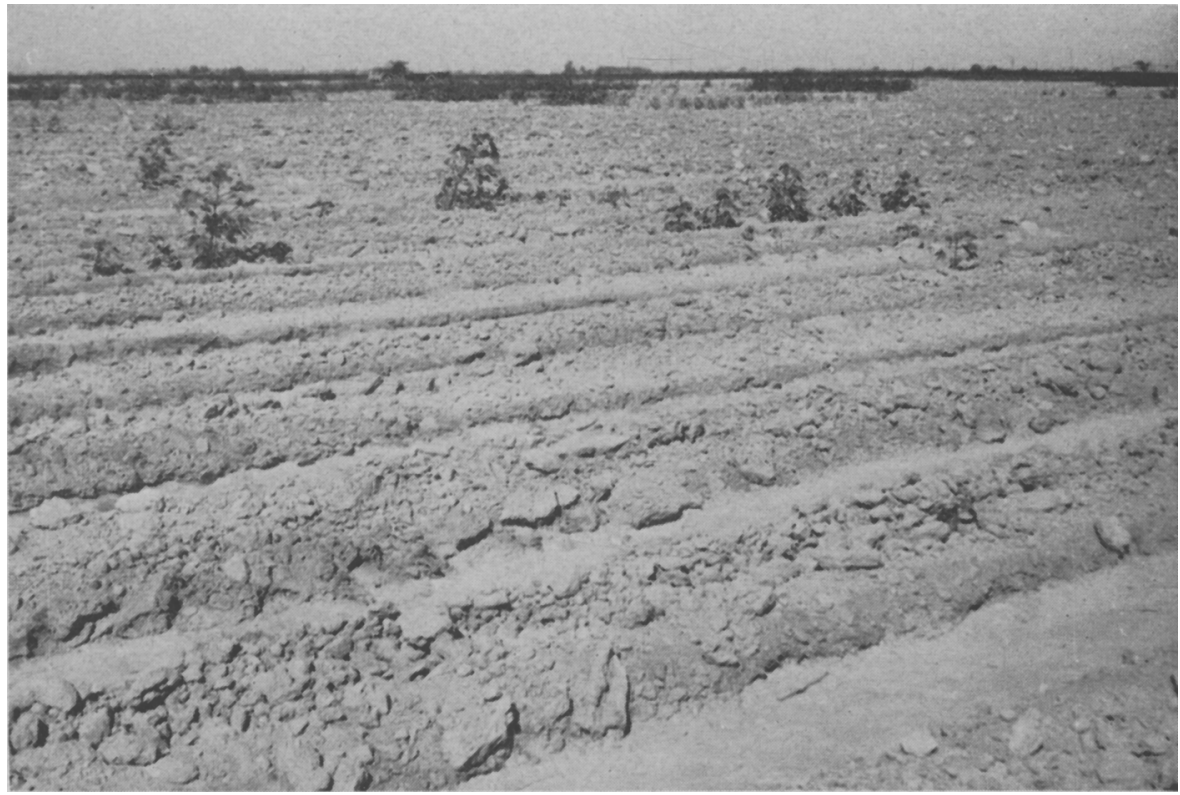

Fig. 1. Photograph taken in fall of 1948 showing site selected for alkali reclamation experiments on the C. H. Upton farm near Kerman, California. The land had been planted to cotton.

TABLE 1

Analyses of original surface samples taken November 12, 1948, from the reclamation plots on the C. H. Upton farm near Kerman, California. Samples are from the first foot of borings situated 100 feet in from the east end of each plot.

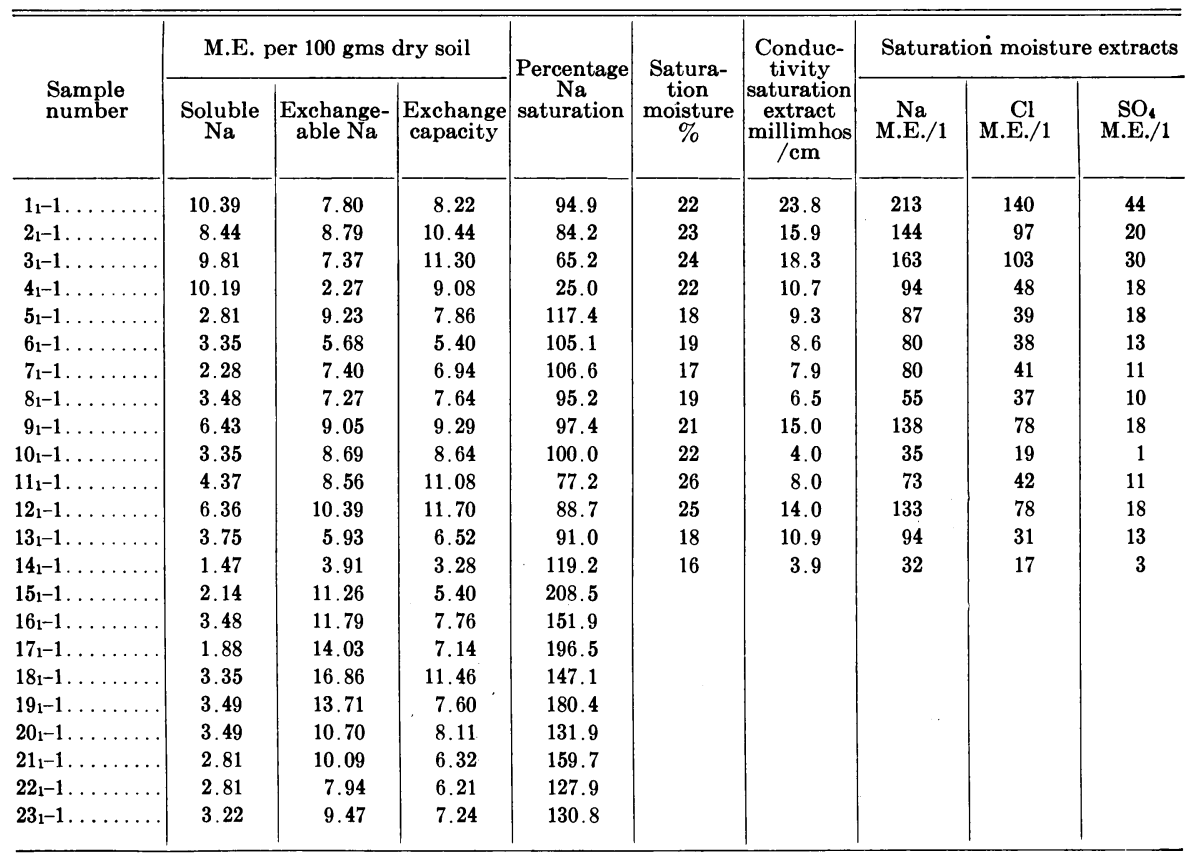

All samples showed the presence of high amounts of undissolved $\mathrm{CaCO}_{3}$. 
high rates to permit the establishment of irrigated pasture. Accordingly, the rate of 1.86 tons of sulfur per acre was selected. The equivalent rates for gypsum and sulfuric acid were 10 tons per acre and 5.70 tons per acre respectively.

The sulfur, gypsum, and sulfuric acid treatments were applied to the plots on December 20-21, 1948. Each treatment was replicated six times and the applications were randomized according to the scheme shown in figure 2. The gypsum and sulfur were applied by means of a conventional fertilizer spreader with a "worm" agitator. The sulfuric acid was sprinkled on the plots in the concentrated form (93 per cent) by means of a special tank truck with a sprinkler devised from iron pipe by Ake Brothers of Goshen, California.

w

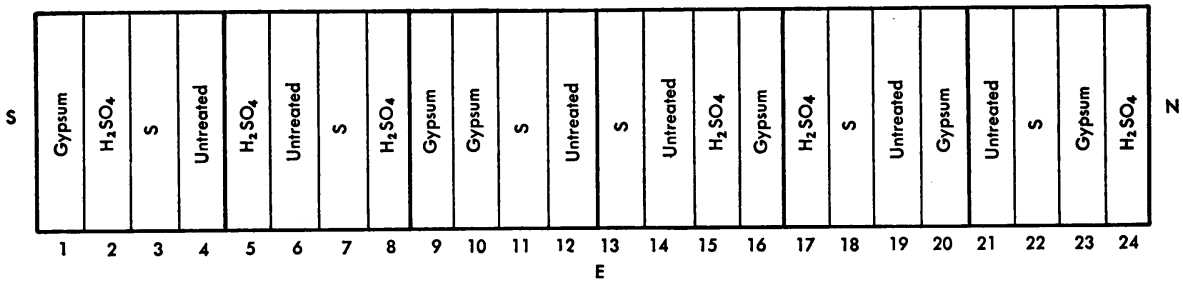

Fig. 2. Diagram showing arrangement of reclamation plots near Kerman, California. Each plot was 15 feet wide and 300 feet long. Plots were seeded to pasture plants.

Following the application of the treatments, the plots were harrowed lightly to incorporate the amendments with the first 1-2 inches of soil.

On January 22, 1949 the plots were irrigated with approximately three inches of water from a well situated about 1,200 feet east of the experimental area. The water from the well had been determined to be an excellent irrigation water with low total salts and a low sodium percentage (36 per cent).

On February 15, 1949, a seedbed was prepared and on February 16 the plots were seeded to the following mixture of alkali-tolerant pasture plants :

Narrowleaf trefoil .................. lbs. per acre

Strawberry clover .................. lbs. per acre

Alsike clover ..................... lbs. per acre

Alta fescue ....................... lbs. per acre

Rhodesgrass $\ldots \ldots \ldots \ldots \ldots \ldots \ldots \ldots \ldots$ lbs. per acre

Dallisgrass ..................... lbs. per acre

Perennial ryegrass .................. lbs. per acre

Following the germination of plants, the plots were irrigated on the average of once a week.

On August 10, 1949, a first cutting of the pasture mixture was made. The mean yields of fresh hay for the various treatments are presented in the second column of table 2 .

A second cutting of the plots was made on November 3,1949 . The mean yields of fresh hay for this cutting are given in the third column of table 2.

During the winter of 1949-50 some of the pasture plants were killed off by frost, particularly the rhodesgrass. Because of this, the plots were reseeded on March 13, 1950, with the same seed mixture as used initially. In reseeding, 
no seedbed was prepared; the seed was broadcast over the plots and the plots were irrigated.

On August 17, 1950, a third cutting of the plots was made. The yields are presented in the fourth column of table 2.

The data presented in table 2 represent the total yields from the plots. Included in the yields are the growths of a number of species of weeds that

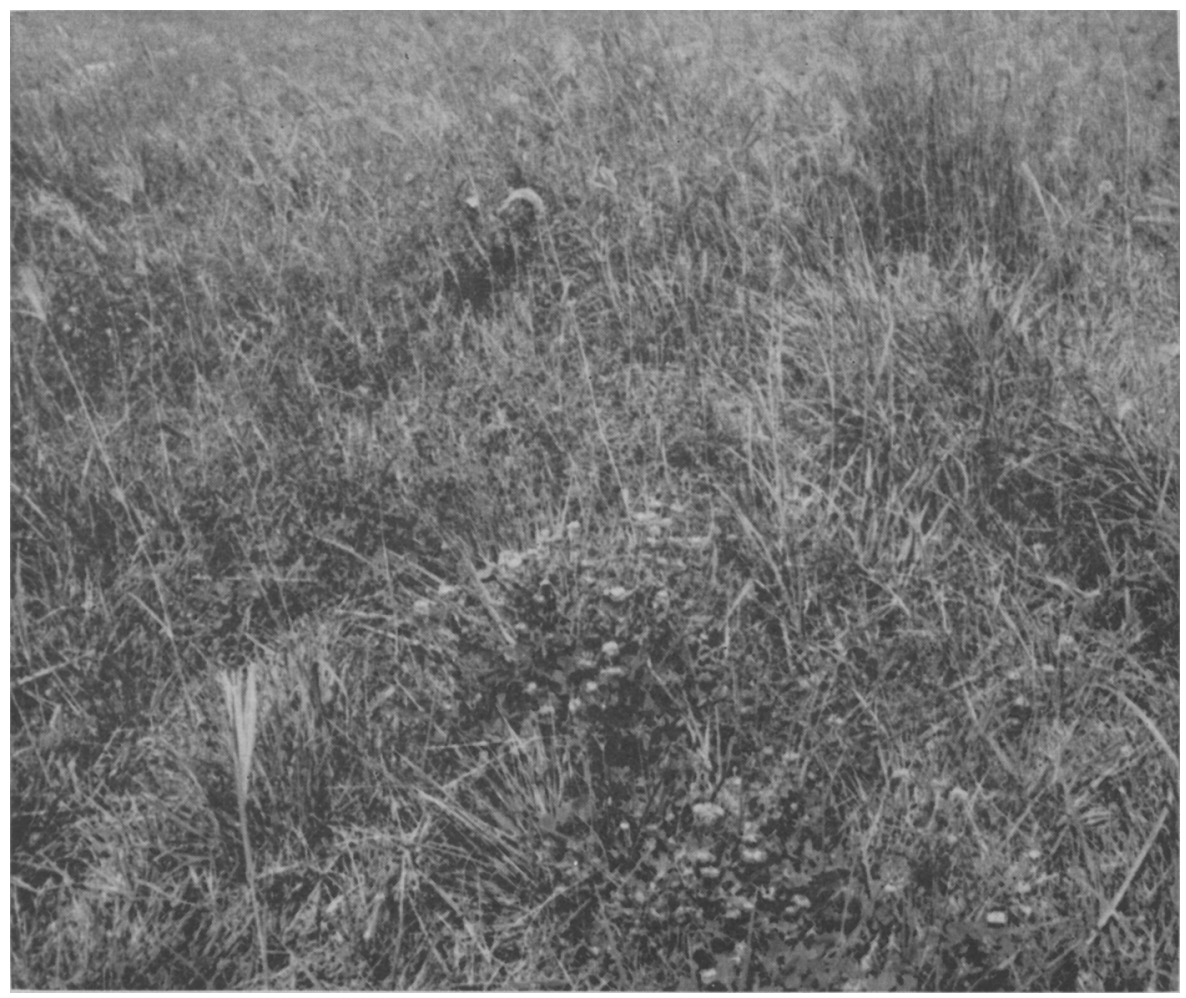

Fig. 3. Photograph taken in August, 1950, showing growth of pasture plants on one of the plots that had been treated with 5.70 tons per acre of $\mathrm{H}_{2} \mathrm{SO}_{4}$.

invaded the plots. Of this, Wislizenia refracta (jackass clover) and Echinochloa crusgalli (watergrass) were most widespread throughout the plots.

In addition to complications due to the presence of weeds, it was noted that the pasture plants did not grow in a constant proportion in the plots. For example, the clovers grew hardly at all on the untreated and sulfur-treated plots, and very sparsely on the gypsum-treated plots. It was only on the sulfuric acid plots that all of the pasture plants were well represented (figure 3 ).

No comprehensive chemical examination of the plot soils has been made since the application of the treatments. However, on July 22, 1949, surface samples $\left(0-12^{\prime \prime}\right)$ were taken from four adjacent plots which included the four different treatments. The samples were taken 100 feet in from the east end of each plot at almost exactly the location of one of the original samplings. In table 3 the analyses of these samples are compared with those of the corre- 
sponding original samples (see table 1 ). Because of the uncertainty as to the correct base exchange capacity of this soil (see p. 124), values for the percentage sodium saturation are not included in the table.

TABLE 2

Yield data for first three cuttings of pasture plants grown on the reclamation plots on the C. H. Upton farm near Kerman, California.

\begin{tabular}{|c|c|c|c|}
\hline \multirow{2}{*}{ Treatment } & \multicolumn{3}{|c|}{ Mean yield, fresh weight, tons per acre } \\
\hline & $8 / 10 / 49$ & $11 / 3 / 49$ & $8 / 17 / 50$ \\
\hline 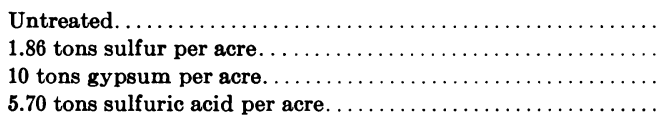 & $\begin{array}{l}1.47 \\
1.71 \\
2.46 \\
3.47\end{array}$ & $\begin{array}{l}1.06 \\
1.17 \\
1.54 \\
1.97\end{array}$ & $\begin{array}{l}0.83 \\
0.77 \\
1.18 \\
2.21\end{array}$ \\
\hline 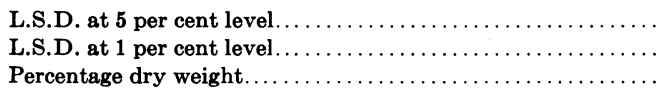 & $\begin{array}{l}0.695 \\
0.96 \\
34.8\end{array}$ & $\begin{array}{l}0.477 \\
0.654 \\
\cdots\end{array}$ & $\begin{array}{l}0.94 \\
1.31 \\
\ldots\end{array}$ \\
\hline
\end{tabular}

TABLE 3

Analyses of surface samples taken from the reclamation plots at Kerman showing the effects of the various treatments on the $\mathrm{pH}$ and sodium content.

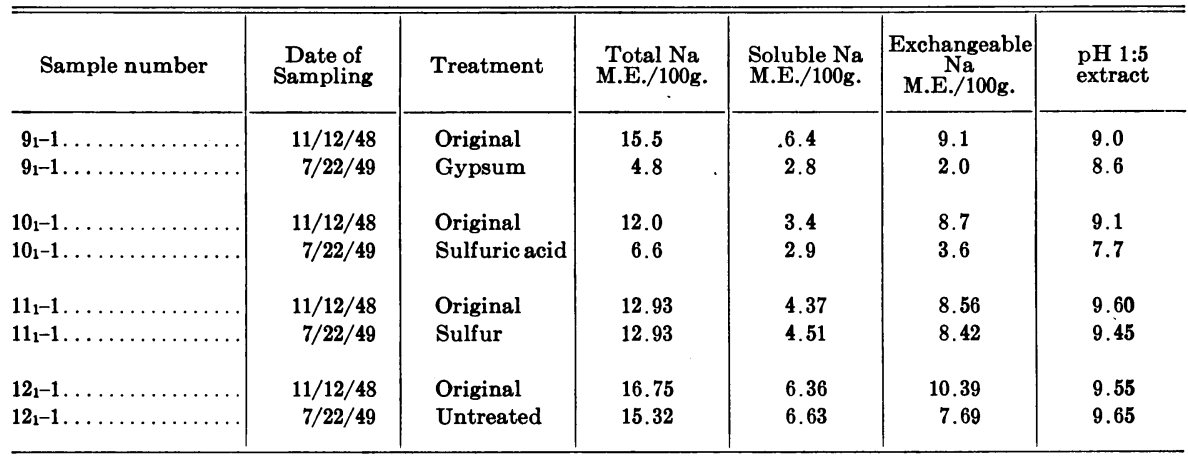

\section{Second Experiment}

In view of the very evident superiority of the sulfuric acid-treated plots over those treated with sulfur and gypsum, a series of new plots was set up in the fall of 1949 in order to determine the effects of considerably smaller applications of the acid. The applications selected were 1.42 and 2.85 tons of $\mathrm{H}_{2} \mathrm{SO}_{4}$ per acre. The new plots were 15 feet by 300 feet in size and adjoined the old plots. Each treatment was replicated six times and the treatments were randomized according to the scheme shown in figure 4. During the week of October 16-23, 1949, the plots were laid out with borders and each plot was deep-chiseled twice as with the old plots. On October 27, 1949, the plots were sampled systematically and the sulfuric acid was applied and mixed into soil in the manner previously described. Thereafter the plots were irrigated at intervals of about 10 days. 
On March 9, 1950, a seedbed was prepared and the new plots were seeded to alfalfa. After germination of the seeds, the irrigation at 10-day intervals was continued.

On August 17, 1950, a first eutting of the new plots was made. The mean yields of fresh hay for the different treatments are given in table 4 .

As with the first experiment, there was considerable invasion of the new plots by weeds (principally by Echinochloa crusgalli). This will be evident

W

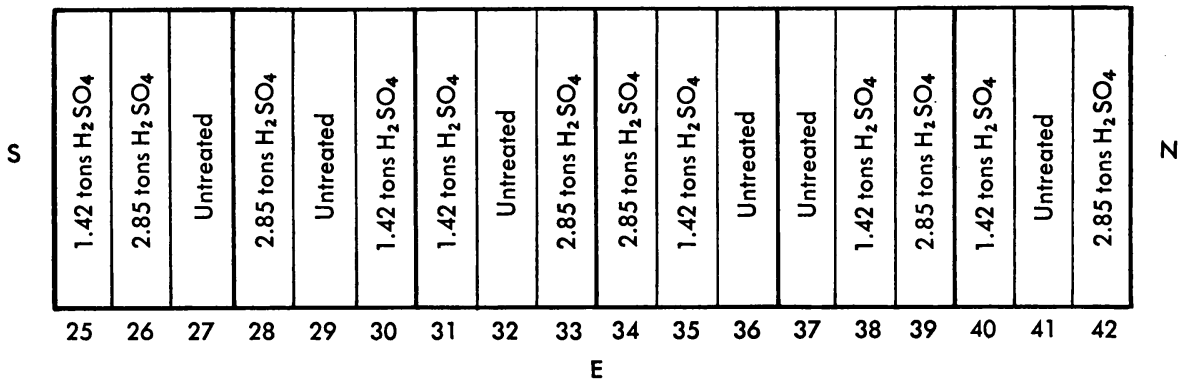

Fig. 4. Diagram showing arrangement of reclamation plots near Kerman, California. Each plot was 15 feet wide and 300 feet long. Plots were seeded to alfalfa.

TABLE 4

Yield data for first cutting of alfalfa grown on the reclamation plots on the C. H. Upton farm near Kerman, California.

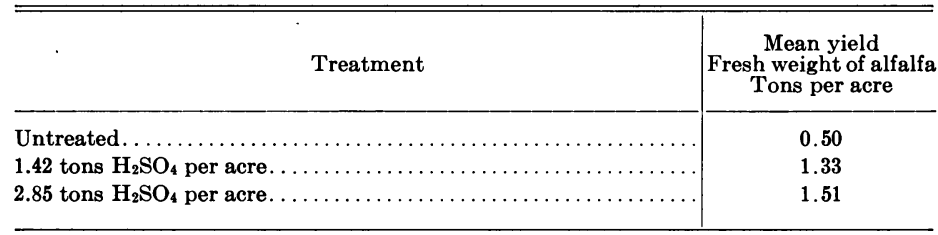

Least significant difference at 5 per cent level $=0.399$ tons per acre.

Least significant difference at 1 per cent level $=0.566$ tons per acre.

from figure 5 which shows photographs taken at the time of the cutting of three adjacent plots, one untreated, one to which 1.42 tons $\mathrm{H}_{2} \mathrm{SO}_{4}$ had been applied, and one to which 2.85 tons $\mathrm{H}_{2} \mathrm{SO}_{4}$ had been applied.

Detailed chemical analyses were made of samples from the new plots before treatment. However, since the analyses showed a very similar alkali condition to the old plots, the chemical results are not reported.

\section{GREENHOUSE EXPERIMENTS}

At the time the new field plots were laid out, a greenhouse experiment was initiated, using approximately one ton of surface soil collected from the new plots at Kerman. The purpose of the greenhouse experiment was to supplement the field experiments with sulfuric acid and to determine the effects of considerably lower applications of the acid than those used in the field.

The experiment was carried out in five-gallon buckets that were provided with drains and catch basins so that the amount of percolate passing through 
the soil could be measured. Twenty-two kilograms of dry soil were placed in each bucket. The resulting soil area in each bucket was $0.162 \times 10^{-4}$ acres.

On November 29-30, 1949, the following treatments were made to the soil in the buckets :

1. Untreated

2. Sulfuric acid, 0.36 tons per acre

3. Sulfuric acid, 0.71 tons per acre

4. Sulfuric acid, 1.42 tons per acre

Each treatment was made in replicates of six and the buckets were randomized to permit a statistical analysis of the results.

TABLE 5

Rate of water percolation through buckets of soil taken from the reclamation plots near Kerman, California. Experiment carried out in the greenhouse at Berkeley.

\begin{tabular}{|c|c|c|c|}
\hline Treatment & $\begin{array}{c}\text { Period } \\
\text { of } \\
\text { leaching }\end{array}$ & $\begin{array}{l}\text { Vol. of } \\
\text { percolate } \\
\text { (average) }\end{array}$ & $\begin{array}{l}\text { Percolation rate } \\
\text { at end of leaching } \\
\text { period, liters/day }\end{array}$ \\
\hline Untreated. & 5 weeks & 20.1 liters & 0.17 liters/day \\
\hline 0.36 tons $\mathrm{H}_{2} \mathrm{SO}_{4} /$ acre $\ldots \ldots \ldots$ & 5 weeks & 24.4 liters & 0.24 liters/day \\
\hline 0.71 tons $\mathrm{H}_{2} \mathrm{SO}_{4} /$ acre. . . . . & 5 weeks & 27.3 liters & 0.47 liters/day \\
\hline 2.50 tons gypsum/acre $\ldots \ldots \ldots \ldots \ldots \ldots$ & 3 weeks & 19.0 liters & 0.17 liters/day \\
\hline
\end{tabular}

Following the application of the acid, the soil in the buckets was then leached for five weeks. In the initial stages of the leaching, two liters of Berkeley tap water $(\sim 50 \mathrm{ppm}$. total salts and very low sodium percentage) were added to each bucket per day. However, as the leaching progressed the permeability of the soils decreased, especially in the case of the untreated soil, so that this initial rate of water application was progressively decreased.

On December 29, 1949, a gypsum treatment was set up in the buckets corresponding to 2.50 tons of gypsum per acre. Following the application of the gypsum, the buckets were subjected to the same leaching procedure as the acid treatments except in this case the leaching period was limited to three instead of five weeks.

The average volume of percolate for each treatment and the mean percolation rate for each treatment at the conclusion of the leaching period are given in table 5 .

According to the table, the leaching of the soils was equivalent to the application of from 11.4 to 18.6 inches of irrigation water.

Following the leaching period, the soils in the buckets were allowed to dry out. On February 3, 1950, they were seeded to alfalfa.

After germination of the seeds, the buckets were sprinkled lightly with tap water each day as considered necessary for the growth of the plants. When well established the plants were thinned out to 15 per bucket.

A first cutting of the alfalfa was made on June 23, 1950 and a second cutting on July 31,1950 . The mean yields of fresh hay, calculated in terms of tons per acre, are presented in table 6 . 

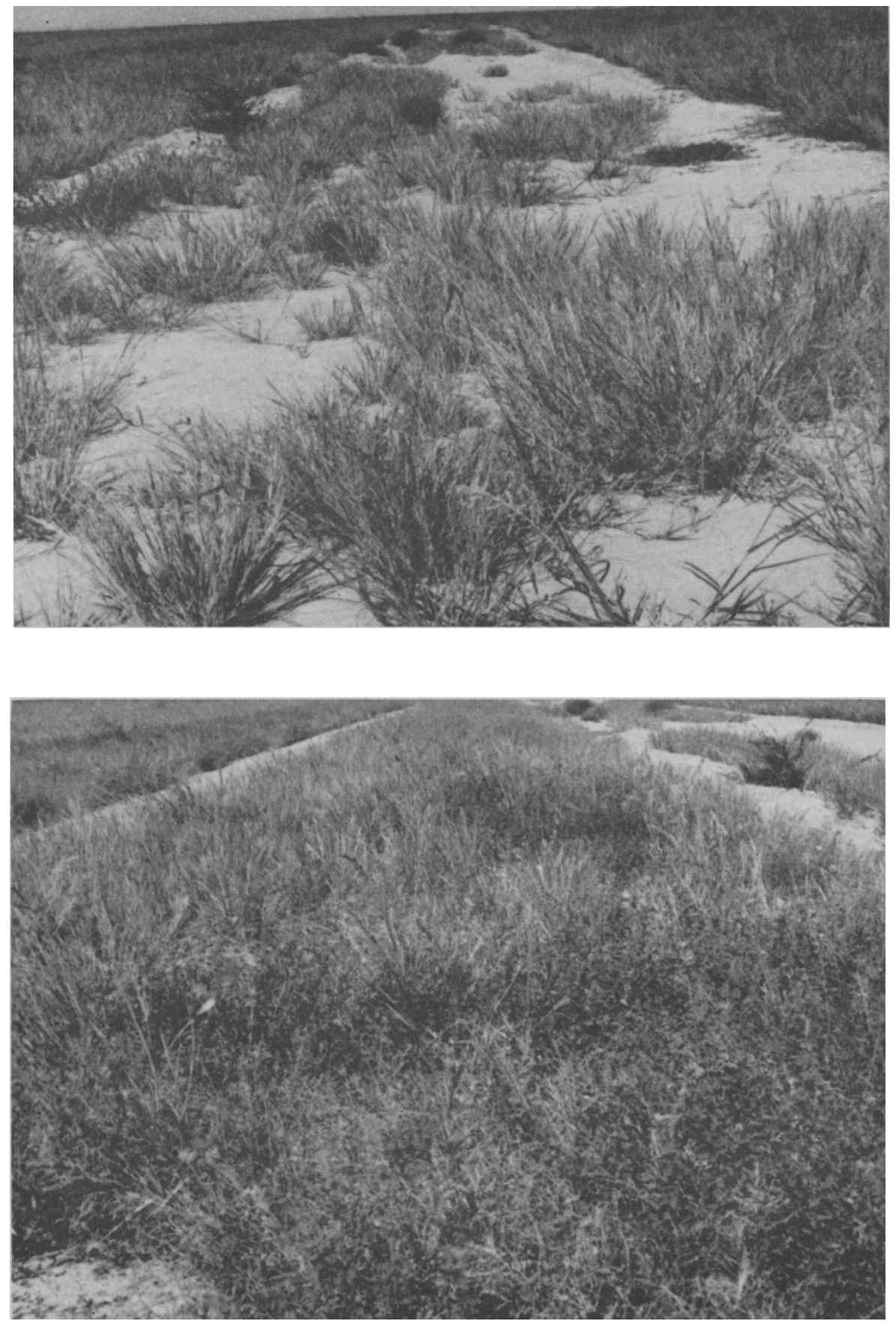


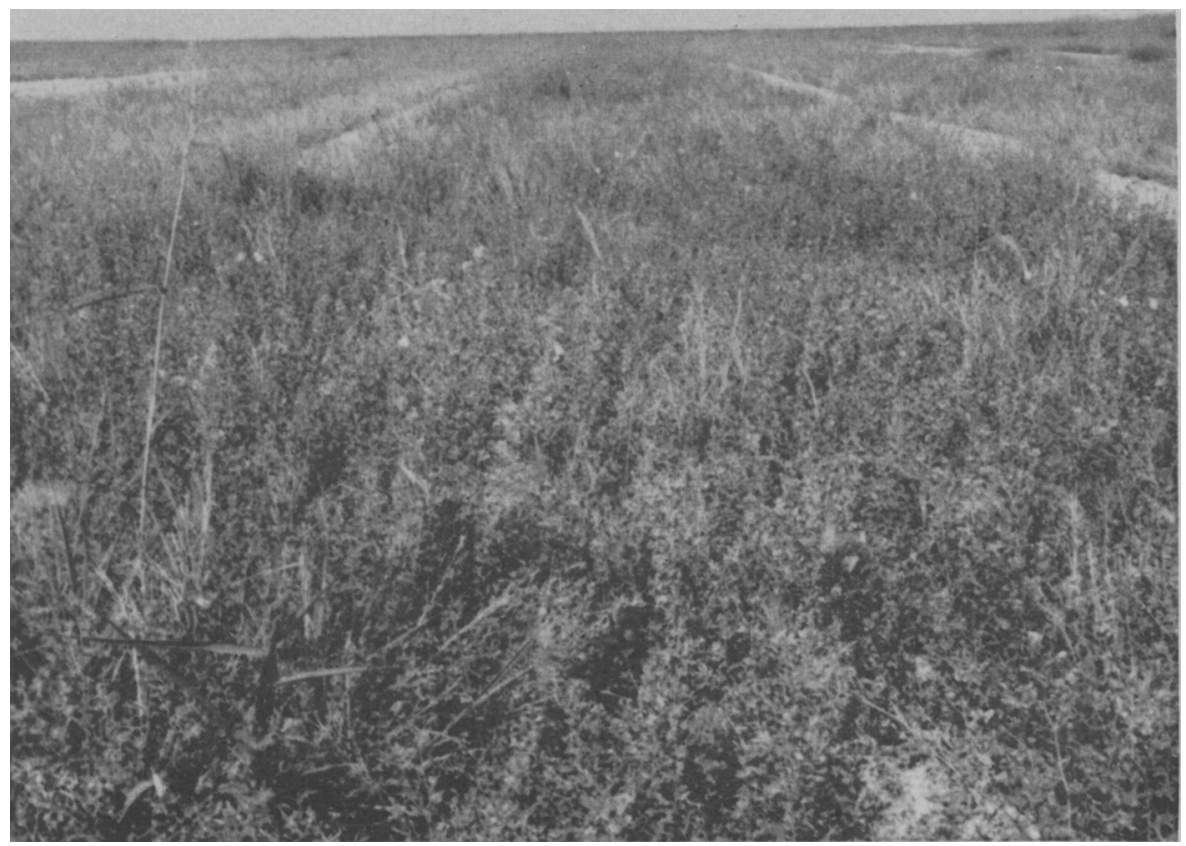

Fig. 5. Photographs taken in August, 1950, of three adjacent plots showing the effects of : no treatment (upper left), 1.42 tons per acre of $\mathrm{H}_{2} \mathrm{SO}_{4}$ (lower left), and 2.85 tons per acre of $\mathrm{H}_{2} \mathrm{SO}_{4}$ (above). Plots had been seeded to alfalfa.

TABLE 6

Yield date of the greenhouse experiment with alfalfa on alkali soil from Kerman, California.

\begin{tabular}{|c|c|c|}
\hline Treatment & $\begin{array}{c}\text { Mean yield } \\
\text { First cutting } \\
6 / 23 / 50 \\
\text { Tons per acre }\end{array}$ & $\begin{array}{c}\text { Mean yield } \\
\text { Second cutting } \\
7 / 31 / 50 \\
\text { Tons per acre }\end{array}$ \\
\hline Untreated.................... & 1.48 & 1.58 \\
\hline 0.36 tons $\mathrm{H}_{2} \mathrm{SO}_{4}$ per acre.... & 6.80 & 9.45 \\
\hline 0.71 tons $\mathrm{H}_{2} \mathrm{SO}_{4}$ per acre $\ldots \ldots \ldots \ldots \ldots \ldots \ldots$ & 8.33 & 12.23 \\
\hline 1.42 tons $\mathrm{H}_{2} \mathrm{SO}_{4}$ per acre $\ldots \ldots \ldots \ldots \ldots \ldots \ldots$ & 8.03 & 14.70 \\
\hline 2.50 tons gypsum per acre $\ldots \ldots \ldots \ldots \ldots \ldots \ldots \ldots$ & 4.90 & 6.80 \\
\hline L.S.D. at 5 per cent level $\ldots \ldots \ldots \ldots \ldots \ldots \ldots \ldots$ & 1.56 & 1.76 \\
\hline L.S.D. at 1 per cent level $\ldots \ldots \ldots \ldots \ldots \ldots \ldots \ldots$ & 2.16 & 2.42 \\
\hline
\end{tabular}

\section{DISCUSSION AND CONCLUSIONS}

The chemical analyses of soils from the experimental plots (table 1) indi. cate a very severe alkali condition of the saline sodic type. Most of the conductivity values of the saturated water extracts are well above the critical value of 4 millimhos/cm that has been set by the U. S. Salinity Laboratory (Richards, 1947$)^{7}$ as the tolerable limit for the growth of sensitive crops. Especially significant are the values for adsorbed sodium which are far in excess of what might be considered permissible.

\footnotetext{
${ }^{7}$ See "Literature Cited" for citations, referred to in the text by author and date.
} 
The reported values for the percentage sodium saturation were calculated from (1) the amount of exchangeable sodium and (2) the base exchange capacity of the soil. The amount of exchangeable sodium was determined by taking the difference between the amount of $\mathrm{Na}$ extractable with $1 \mathrm{~N}$ neutral $\mathrm{NH}_{4}$ Ac and the quantity of $\mathrm{Na}$ dissolved in a 1:5 water extract of the soil. The base exchange capacity of the soil was determined by (1) replacing the exchangeable cations with $\mathrm{NH}_{4}{ }^{+}$by leaching with $1 \mathrm{~N}$ neutral $\mathrm{NH}_{4} \mathrm{Ac}$, (2) removing the excess $\mathrm{NH}_{4}$ Ac with methyl alcohol, (3) distillation of the $\mathrm{NH}_{4}{ }^{+}-$ saturated soil with $\mathrm{Ba}(\mathrm{OH})_{2}$, and (4) determining the amount of $\mathrm{NH}_{3}$ distilled over by catching it in standard acid.

In a separate research to be reported elsewhere, it has been found that the values obtained for the percentage sodium saturation of over 200 per cent are the result of an error in the determination of the base exchange capacity. This error arises from the fact that this particular soil possesses an unusual capacity for the fixation of $\mathrm{NH}_{4}{ }^{+}$ion in a difficultly exchangeable form. A number of such soils have been reported on recently by Bower (1950). The fixation is such that the $\mathrm{NH}_{4}^{+}$cannot be completely released by distillation with either $\mathrm{Ba}(\mathrm{OH})_{2}$ or $\mathrm{Mg}(\mathrm{OH})_{2}$. A correct value for the base exchange capacity of this soil can be obtained by distillation of the $\mathrm{NH}_{4}$-saturated form with strong $\mathrm{NaOH}$. When exchange-capacity values determined by distillation with $\mathrm{NaOH}$ are used, the high percentage sodium saturation figures of the table are reduced to approximately 100 per cent.

It appears, therefore, that we are justified in assuming that this soil is 100 per cent saturated with sodium. On this basis, an application of about 12.5 tons per acre of gypsum would be required to reduce the first foot of soil to the level of 10 per cent sodium saturation. The levels chosen of 10 tons per acre of gypsum, 5.70 tons per acre of $\mathrm{H}_{2} \mathrm{SO}_{4}$, and 1.86 tons per acre of sulfur were the result of calculations of this kind, even though it was realized that applications at this level would not be economically feasible.

The yield values for the first cutting on August 10, 1949 (table 2), show a highly significant superiority of $\mathrm{H}_{2} \mathrm{SO}_{4}$ over the other treatments. The yields from gypsum plots are significantly higher than the untreated and sulfur plots. The yields from the sulfur plots are not significantly different from those of the untreated plots.

A somewhat similar picture is shown by the yields of the second cutting of November 3, 1949 (table 2). Here also the $\mathrm{H}_{2} \mathrm{SO}_{4}$ plots show a high degree of superiority over the untreated and sulfur plots, although they are not significantly better than the gypsum plots. Again the sulfur plots are not significantly different from the untreated plots.

A change in the picture for gypsum is shown in the yields of the third cutting taken approximately one year after the first cutting (table 2). These results show no significant difference between the untreated, sulfur, and gypsum plots. On the other hand, it is quite evident that the superiority of the $\mathrm{H}_{2} \mathrm{SO}_{4}$ plots has persisted into the second year.

In view of the well-established beneficial effects of sulfur noted elsewhere (Kelley, 1937), the ineffectiveness of the sulfur treatments on the Kerman plots deserves comment. The explanation that most readily presents itself is that insufficient time has elapsed for the oxidation of the sulfur. It seems 
entirely possible that the action of oxidizing microorganisms may have been inhibited by the very severe alkali condition of the Kerman soil. If this should prove to be the case, the effects of the sulfur treatments may manifest themselves as the experiment is continued.

Visual inspection of the plots at the time of the third cutting (August 17, 1950) revealed a general improvement of growth on all of the plots, even on the untreated plots, over that of the first year. However, the growth on the untreated plots was represented considerably by weed growth such as $E$ chinochloa crusgalli. As mentioned previously, the $\mathrm{H}_{2} \mathrm{SO}_{4}$ plots appeared strikingly better due to a luxuriant growth of the clovers, which were nearly absent in the untreated and sulfur plots and only moderately represented in the gypsum plots.

The chemical analyses of soil samples, taken from identical locations immediately before and seven months after the treatments and summarized in table 3 , indicate very little change in the sodium content and $\mathrm{pH}$ of the sulfurtreated and untreated soils. In contrast, a marked reduction in the total, soluble, and exchangeable sodium is observed in the gypsum- and sulfuric acid-treated soils. In the case of the sulfuric acid-treated soil a substantial reduction in $\mathrm{pH}$ has occurred. On the other hand, the pronounced differences between the gypsum-treated and $\mathrm{H}_{2} \mathrm{SO}_{4}$-treated soils in terms of crop yields are not reflected in the chemical analyses. This fact is in support of the general observation that the plant itself is a much more sensitive indicator of the efficacy of a reclamation procedure than any known chemical test.

The clear and persistent superiority of sulfuric acid over sulfur and gypsum in the reclamation of the Kerman alkali soil is not easily explained by means of chemical considerations such as those embodied in equations (1)(4). Moreover, the problem of the action of $\mathrm{H}_{2} \mathrm{SO}_{4}$ is not simplified by the yield results for the first cutting of the new plots (table 4). In this experiment the much lower applications of 1.42 and 2.85 tons per acre of $\mathrm{H}_{2} \mathrm{SO}_{4}$ were used. However, although the sulfuric acid plots were better to a high degree of significance than the untreated plots, the two applications of the acid were not significantly different; that is, the application of 1.42 tons per acre of $\mathrm{H}_{2} \mathrm{SO}_{4}$ produced essentially the same effect as twice that amount. This result, although adding to the complexity of the problem theoretically, nonetheless suggests that the use of sulfuric acid may be economically practical in the amelioration of even severe alkali conditions such as the one under study.

The greenhouse experiments suggest that favorable results in the reclamation of the Kerman alkali soil may be expected from $\mathrm{H}_{2} \mathrm{SO}_{4}$ applications of as low as 0.36 tons per acre (table 6 ). The data of this experiment concerning the initial leaching period (table 5) seem of particular interest and suggest the necessity for more elaborate experiments in this direction. At the start of the leaching period, all of the treatments (including the untreated soil) were characterized by rather high percolation rates (two liters per day per bucket or greater). As the leaching progressed the percolation rate of the untreated soil decreased rapidly, until after five weeks it amounted to only 0.17 liters per day. With the gypsum-treated soils, the rate decreased to 0.17 liters per day in only three weeks. In the cases of the $\mathrm{H}_{2} \mathrm{SO}_{4}$-treated soils, considerably higher percolation rates were maintained at the end of five weeks of 
leaching. Among the different applications of $\mathrm{H}_{2} \mathrm{SO}_{4}$ the final leaching rate varied directly with the amount of acid applied.

The foregoing experiments and discussion have dealt with the relative effects of applications of gypsum, sulfur, and sulfuric acid on the reclamation of a saline sodic soil of the Fresno series. The observed, and as yet unexplained superiority of sulfuric acid must be considered in terms of the particular soil investigated, at least for the time being. Although the Fresno series is representative of an extensive area of alkali-affected soil, generalizations involving other soil types cannot be drawn from the data of the present research. Experiments along the lines of those reported with sodic soils of widely different series are in progress or are projected and will be described later.

\section{SUMMARY}

Gypsum, sulfuric acid, and sulfur were applied in the equivalent amounts of $10,5.70$, and 1.86 tons per acre respectively to a severely affected alkali soil of the Fresno series. Effects of the soil correctives on the yield of irrigated pasture were compared statistically.

For the period of approximately two years after application of the treatments, the yields of the sulfuric acid-treated plots were markedly higher than those of the plots treated with gypsum and sulfur.

The yields of the gypsum-treated plots were significantly higher than those of the sulfur-treated and check plots for the initial cuttings. However, 20 months after the application of the treatments there was no significant difference among yields of the three groups.

Throughout the two-year period, yields of the sulfur-treated plots were not significantly higher than those of the untreated plots. This was probably because insufficient time had elapsed for the oxidation of the sulfur.

Pronounced beneficial effects on the same soil were observed following sulfuric acid applications of 2.85 and 1.42 tons per acre. Greenhouse experiments indicated that improvement of this soil may be expected from applications of as low as 0.4 tons of acid per acre. 


\section{LITERATURE CITED}

BowER, C. A.

1950. Availability of ammonium fixed in difficultly exchangeable form by soils of semiarid regions. Soil Sci. Soc. Amer. Proc. 15:119-22.

Kelley, W. P.

1937. The reclamation of alkali soils. Calif. Agr. Expt. Sta. Bul. 617:1-40. (Out of print.) Richards, L. A. (Ed.)

1947. Diagnosis and improvement of saline and alkali soils. U. S. (Regional) Salinity Laboratory, Riverside, Calif. 157 p. U. S. Dept. Agr., Bureau of Plant Industry, Soils, and Agricultural Engineering. 

The journal Hilgardia is published at irregular intervals, in volumes of about 600 pages. The number of issues per volume varies. Subscriptions are not sold. The periodical is sent as published only to libraries, or to institutions in foreign countries having publications to offer in exchange.

You may obtain a single copy of any issue free, as long as the supply lasts; please request by volume and issue number from:

\section{Publications Office \\ College of Agriculture \\ Berkeley 4, California}

The limit to nonresidents of California is 10 separate issues on a single order. A list of the issues still available will be sent on request. 